\title{
E्己̌reAãa Disability, Deafness and Ideology in the late Twentieth and earty Twenty-first Centuries
}

Patrick McDonnell'

'University College Dublin (UCD), Dublin - Ireland

\begin{abstract}
Disability, Deafness and Ideology in the late Twentieth and early Twenty-first Centuries. Ideology constitutes an important site of struggle for disabled people and for Deaf communities. In recent decades two ideologies - normalisation and rights - have offered different answers to the question of what it means to be disabled or Deaf. Both ideologies emerged in the post World War II period; both challenged long-established institutional structures and professional practices; and both appealed to notions of human and civil rights. However, normalisation is fundamentally paternalistic where reform is seen to be a matter for professional expertise and to be negotiated in academic circles and in the domains of professional practice. In contrast, a rights ideology is based on a social model of disability and a socio-cultural model of deafness that oppose the exclusion of disabled and Deaf people from strategic and participative roles in defining the issues, in policy making, and in decision taking. Where normalisation seeks to eradicate or attenuate difference, a rights' perspective advocates recognition and respect for difference; where normalising ideology looks to expertise and organisational change for solutions, disability movements and Deaf communities argue that the most satisfactory answers are to be found in the fields of politics and power.
\end{abstract}

Keywords: Deaf community. Disability. Ideology. Normalisation. Rights.

RESUMO - Deficiência, Surdez e Ideologia no Final do Século XX e Início do Século XXI. A ideologia constitui um importante campo de luta para pessoas com deficiência e para as comunidades Surdas. Nas últimas décadas, duas ideologias - a da normalização e a dos direitos - têm oferecido diferentes respostas à questão do que significa ser deficiente ou Surdo. Ambas as ideologias emergiram no período após a Segunda Guerra Mundial, desafiaram práticas profissionais e estruturas institucionais há muito estabelecidas e recorreram às noções de direitos civis e humanos. Contudo, a da normalização é fundamentalmente paternalista na medida em que a correção é vista como uma questão de competência profissional, negociada em círculos acadêmicos e domínios de prática profissional. Em comparação, uma ideologia dos direitos é baseada em um modelo social de deficiência e em um modelo sociocultural de surdez que se opõem à exclusão dos Surdos e das pessoas com deficiência de funções estratégicas e participativas na definição de problemas, na formulação de políticas e na tomada de decisões. Enquanto a normalização procura erradicar ou atenuar a diferença, uma perspectiva dos direitos defende o reconhecimento e o respeito à diferença; enquanto a ideologia normalizadora busca soluções na competência e nas mudanças organizacionais, os movimentos de pessoas com deficiência e das comunidades Surdas defendem que respostas mais satisfatórias podem ser encontradas no campo da política e do poder.

Palavras-chave: Comunidade Surda. Deficiência. Ideologia. Normalização. Direitos.

Educação \& Realidade, Porto Alegre, v. 41, n. 3, p. 777-788, July/Sept. 2016.

777

http://dx.doi.org/10.1590/2175-623661091 
Disability, Deafness and Ideology in the late Twentieth and early Twenty-first Centuries

\section{Introduction}

In contemporary Ireland, and indeed internationally, the relationship between disabled people ${ }^{1}$ and society is undergoing radical change (Oliver, 1990; Barnes; Mercer, 2003). Change is manifest in fields as diverse as legislation, education, research, service provision and even in the meaning of disability itself. The promise of these initiatives is that they will end or, at the very least, minimise decades of discrimination and exclusion. Any attempt to understand this process requires an exploration of what we might call the deep structures of the relationship between disability and society - the prevailing and often taken-for-granted beliefs, ideas and values which shape that relationship (McDonnell, 2000).

Similar changes are taking place in the relationship between Deaf $^{2}$ communities and hearing societies. While some theorists in Deaf studies (see for example, Ladd, 2003 and Lane, 2002) reject the notion that Deaf people can be seen as disabled, Deaf people and disabled people share a history of discrimination and have been subject to similar forms of exclusion and oppression in the past (Barnes; Mercer, 2003; Lane; Fischer, 1993; Oliver, 1990). This paper recognises considerable overlap in the experiences of Deaf and disabled communities but also accepts that there are also significant differences between the two groups.

In their analyses of social, political and cultural relations involving disability and deafness, scholars have identified several important ideologies - examples include medicalisation, institutionalisation and eugenics - around which responses to disability and deafness have been organised (Barnes; Mercer, 2003; Lane, 1993; McDonnell, 2007; Oliver, 1990). This paper adopts a Gramscian approach to ideology (Gramsci, 1971). In this sense, ideas and values can be used by the powerful to sustain their position and promote their interests. However, it is also possible to foster ideas and values that challenge the domination of the powerful and to promote an alternative account of how things might be. Gramsci's approach to ideology both as a hegemonic process and as an instrument of social transformation is particularly relevant to an exploration of both disability relations and Deaf relations in society. One the one hand, a relation of domination has been one of the most characteristic features of these relations in western societies since early modern times (McDonnell, 2007). On the other hand, as we shall see, the emergence of a social model of disability and a socio-cultural model of deafness reflects a challenge to this domination and offers alternative understandings of the nature of the relationships involved.

A discussion of all of these ideologies is beyond the scope of this paper; here, I focus on the most recent developments and on two particular ideologies - normalisation and disability / Deaf rights - that have underpinned change in the late twentieth and early twenty-first centuries. In the next section of this paper I describe the ideology and

778 Educação \& Realidade, Porto Alegre, v. 41, n. 3, p. 777-788, July/Sept. 2016. 
practice of normalisation and the general context in which it emerged. I discuss its distinctive characteristics first in relation to disability and then in relation to deafness. A further section addresses the ideology of rights and the development of fundamental challenges to medical models of disability and of deafness. The final section consists of a brief discussion on the impact and implications of normalisation and rights' perspectives.

\section{Normalisation}

In the post-World War II period, opposition to the segregation and institutionalisation of disabled people - widespread practices in western society for a century and a half - reached a critical point. The basic argument was that disabled people had a right to more normal and humane experiences, something that was being denied them if they were segregated from mainstream society. Normalisation emerged as an initiative largely among professionals, involving non-disabled practitioners, academics and researchers (Deeley, 2002). The major critique of prevailing theories and practices was located among members of professions directly involved in the fields of disability or deafness, such as psychiatry, psychology and education.

In one typical analysis, Vail (1966, p. vii) summarises the case against the institutional thinking and practices that prevailed. According to this account, the critique of segregation and institutionalisation reflected "[...] astonishing advances in social attitudes and policy" and involved "consciously undoing harsh traditions and replacing them with penetrating and unsentimental humanism". In the past, "institutional relationships" had constrained individual expression and initiative, had fostered dependence and were employed as instruments of control rather than as means of promoting acceptable change; individuals were dehumanised and degraded because they were "put away" and subjected to "inescapable ... humiliations" (Vail, 1966, p. viii).

Like many critics, Vail (1966, p. ix) argued for the kind of reform that would be committed to humane interventions, would reflect authentic and enlightened values, introduce self-critical and self-correcting mechanisms, foster constructive change and independence, and dispense with restrictive and punitive measures. There was, in addition, the more general expectation that new policies and practices would be based on "day treatment and other forms of care in the community" and would promote individualised responses "in the face of increasing mass uniformity in society".

This critique of institutionalisation and segregation was related to the larger political and social changes that were taking place in western society during this period. Firstly, the post-war period witnessed a convergence of ideas, attitudes and movements concerned with human and civil rights. Revelations of the atrocities carried out under the 
Disability, Deafness and Ideology in the late Twentieth and early Twenty-first Centuries

Nazi regime sensitised western society to the rights of minorities and to their protection. Moreover, in the context of cold war politics, contradictions were becoming apparent between claims about social justice and freedom for all, and the actual experiences of particular social groups. Some of these concerns were expressed in a variety of UN charters and other conventions formulated during this period, including the UN Declaration on the Rights of Mentally Retarded Persons in 1971 and the Declaration of the Rights of Disabled Persons in 1975 (Faughnan; O'Connor, 1980; Whitehead, 1992).

Secondly, social groups with long historical experiences of oppression began to articulate a social justice agenda through civil rights and women's movements (Whitehead, 1992). These new social movements were prepared to pursue civil rights and social justice goals on the streets, in politics and in the courts. In addition, the courts, especially in the US, seemed prepared to push out the boundaries of rightsbased social policy (Bannerman Foster, 1987). Thirdly, critical and well-publicised descriptions of public institutions appeared, graphically describing the abuse, filth, and over-crowding suffered by patients (Levine, 1981; Morris, 1993; Talbot, 1978). Sociological investigations, based on interpretive research paradigms, raised similar concerns (Goffman, 1961), including the class, gender and racial biases of institutionalisation (Mercer, 1974; Talbot, 1978). Studies of this kind alerted public opinion to the rights of patients in psychiatric hospitals, to the treatment of people with learning difficulties in institutions, and to the experiences of students in special education.

Finally, the emergence of the modern welfare state inaugurated an era of social citizenship in which access to education, health and social security was underwritten by the idea of social rights (Thomson, 1998). The question of how social rights might be exercised, with regard to different social groups, prompted a review of professional services within the institutions themselves. In addition, conflicts between the 'old school' medical autocracy and the new professionals - nurses, psychologists, teachers, social workers - provided fertile ground for critical debate (Tyne, 1992).

The ideology of normalisation was expressed in different ways in different parts of the social system - in the integration movement in education, in deinstitutionalisation in the mental health sector, and in normalisation in relation to people with learning difficulties. Normalisation was the explicit premise of Wolfensberger's (1972) case against segregated institutions for people with learning difficulties: such institutions produced devalued identities for the people within them and reinforced negative attitudes among people outside. In a similar vein, arguments against segregated special education highlighted its negative impact on the emotional, social and academic development of pupils with perceived impairments (Barton, 1995). In the treatment of mental illness, the aims of normalising behaviour and of building social net-

780 Educação \& Realidade, Porto Alegre, v. 41, n. 3, p. 777-788, July/Sept. 2016. 
works were seen to be incompatible with an institutional environment (Prior, 1991).

Normalisation involves at most the elimination, or at least, the reduction of difference. With regard to learning difficulties, Szivos (1992) identifies two distinct normalising responses in Wolfensberger's approach: a means criterion and a behaviour criterion. The means of normalisation refers to the need for the environment to highlight and promote images and attitudes that emphasise an individual's similarity to, rather than difference from, others. The behaviour criterion involves promoting individual competence "beyond the point of being merely physically adaptive, to the point of being socially normative" (Szivos, 1992, p. 113). Thus, in education the integration movement is "inherently assimilationist" (Corbett; Slee 2000, p. 134) with the expectation that the integrated pupil is 'ready for' and 'able to cope' in the 'normal' mainstream school. The fact that mainstream schools were significantly abnormal in their social class, gender and ability relations has never been a factor in the integration debate (McDonnell, 2003). In the field of mental health, normalising ideology places a high moral and therapeutic value on community care as opposed to treatment in the institution.

Normalising ideology has a somewhat longer history in relation to Deaf communities than it has in relation to disability. In the first half of the nineteenth century, the work of abbe de l'Epee in Paris led to the rapid expansion of Deaf education in Europe and beyond (Lane, 1984; Lane; Fischer, 1993). Epee's 'French method' gave a central role to signing rather than speech in teaching and learning. However, during the second half of the century, the majority of schools in Europe began a shift towards oralism. In general terms, oralism or oral education refers to a particular pedagogic and organisational approach adopted in schools for Deaf children. It does not recognise the cultural or linguistic standing of Deaf communities and its primary aim is the assimilation of Deaf children into hearing society. Oralist teaching programmes put great emphasis on the teaching and acquisition of spoken language skills, do not use sign language, and generally prohibit its use with and among Deaf children (Lane, 1993; McDonnell; Saunders, 1993).

In the case of Ireland, normalising ideology of this kind characterised Deaf education from the late 1950s onwards (Crean, 1997; Ireland, 1972). However, in this normalising project there was one major contradiction: Deaf schools were de facto signing communities and while the official curriculum stipulated spoken language and forbade signing, the hidden curriculum continued to reflect a signing community (McDonnell; Saunders, 1993); while school regulations might forbid signing, Deaf pupils had no other realistic or effective means of communication with one another.

Normalisation continues to operate in a number of ways in the education of Deaf students in Ireland. The Education Act (Ireland, 1998a), for example, recognises that Irish Sign Language (ISL) has a role in edu- 
Disability, Deafness and Ideology in the late Twentieth and early Twenty-first Centuries

cation. However, the act also formulates this role in minimalist terms: it recommends ISL as one of the support services for Deaf students. Thus, the act overlooks the potential of ISL to operate as a primary language in education and implicitly supports the view that a major function of schools is not so much to educate Deaf students, but rather to facilitate their assimilation into hearing society.

Normalisation has proved to be very durable in terms of ideology and practice not only in education but through the social services. It is attractive to professionals because it is congruent with the notion of professional expertise. It appeals to politicians and policy makers because its programmes prompt reform without demanding a more radical transformation of existing services. Normalisation has provided a powerful critique of segregation and institutionalisation. However, its emphasis on policies of dispersal and assimilation, as appropriate responses to discrimination and exclusion, stand in opposition to egalitarian measures such as recognition and solidarity which are essential to a rights perspective (Kwiotek; McDonnell, 2003).

\section{Disability Rights and Deaf Rights}

In the post World War II period the ideology of normalisation overlapped with another, very different perspective based on ideas of social justice and civil rights. In the latter case, opposition to discrimination and exclusion coalesced around what became known as the disability movement and the social model of disability. Both normalisation and disability rights' perspectives challenged the same long established ideologies and practices of segregation and institutionalisation. But there were fundamental differences between the two movements. Normalisation was primarily paternalistic. Programmes of reform were organised for the most part by professionals, were aimed at politicians, academics, administrators and other professionals in the social services, and were negotiated mainly in academic circles or the domains of professional practice. No strategic or participative roles were available for disabled people in this debate, nor in the arenas where policies were made and decisions taken. In normalisation, while disabled people were seen to be disempowered and discriminated against, they were also regarded as helpless and dependent. The professionals who argued for reform saw themselves as interpreters of what was in the best interests of disabled people.

From the 1960s onwards, the social model of disability began to gain momentum in western society (Barnes, 1996; 1998; Tregaskis, 2002). Although this perspective or model took somewhat different forms in different places and at different times, the forms all shared important features. Firstly, the social model made a distinction between impairment and disability and challenged the idea of disability as a personal deficit or tragic condition. Secondly, it proposed that disabil-

782 Educação \& Realidade, Porto Alegre, v. 41, n. 3, p. 777-788, July/Sept. 2016. 
ity is the product of a relationship between individuals and their environments. Environments - architectural structures, economic practices, social policies, occupational procedures, health services, legal processes, educational systems, and so on - have been organised and structured over time and represent social and political choices. When a particular structural or organisational form excludes certain groups of people, it is this inequality that causes disability. From this perspective, disability is a form of discrimination. As Harlan Hahn (1985, p. 128) put it, "[...] disability stems from the failure of a structured social environment to adjust to the needs and aspirations of citizens with disabilities rather than from the inability of a disabled individual to adapt to the demands of society." Thus, the emergence of a social model shifted the focus of analysis from individuals and their perceived impairments to environments, inclusion and rights. This model also expressed 'insider' perspectives in that the leading advocates were disabled people whose theories were closely linked to political activism (Oliver, 1990).

There is general agreement that the development of a social model of disability has been instrumental in politicising disabled people and their allies throughout the world (Barnes, 1998; 2000; Tregaskis, 2002). It has shifted attention from psycho-medical conditions to civil and human rights. It has provided a conceptual foundation for an analysis of the social production of disability in the modern world and has supplied a framework for understanding and explaining processes of discrimination experienced by disabled people.

Like the disability movement, Deaf communities have also been involved in a process of social, political and cultural transformation. The development of a cultural model of deafness shared many of the features of the social model of disability. Both appealed to ideas of basic human and civil rights. Both referred to political values that claimed to vindicate those rights and actual social practices that led to discrimination and injustice. Both had available the same master frames of reference, such as civil rights movements and women's movements, for formulating concepts and mobilising support (McAdam, McCarthy; Zald, 1996).

Although it was not always articulated in the same way, the notion of Deaf rights has a long history in Deaf communities. At the beginning of the nineteenth century Jean-Marc Itard, the resident physician at the National Institution for Deaf-Mutes in Paris, carried out experiments on Deaf students in an attempt to locate the lesion that he believed might be the cause of deafness (Lane, 1984). His aim was to try to establish a rational and scientific basis for treatment. However, Itard's model of deafness was not the only one available: Jean Massieu, a Deaf teacher at the National Institution proposed an alternative model (Lane, 1984) Massieu pointed out that a Deaf community existed, that this community had a distinctive language, sign language, and that for Deaf people deafness was more a matter of educational opportunities than a ques- 
tion of disease or lesions of the ear. Nevertheless it was Itard's definition that prevailed and it was Itard who contributed the entry on deafness in the major medical encyclopedia of the period (Lane, 1984). Itard's successor as resident physician in the Paris school, Prosper Ménière, made explicit the nature of the relationship that he believed should exist between the expert and the anomalous subject:

The deaf believe that they are our equals in all respects. We should be generous and not destroy that illusion. But whatever they believe, deafness is an infirmity, and we should repair it whether the person who has it is disturbed by it or not (apud Lane 1984, p. 134).

For most of the nineteenth century, physicians became the accepted experts on deafness. They defined the issues, set the boundaries on how these might be investigated, and mobilised the appropriate social and cultural responses (McDonnell, 2007). The impact of scientific medicine on deafness is evident in the shift towards oral education that occurred over the course of the century and in the resolutions of the congresses on Deaf education that took place in the last quarter of the nineteenth century. While the spread of oralism in special schools for Deaf children led to greater discrimination against Deaf people, it was possible for Deaf communities to organise resistance to these ideas using an alternative model of deafness based on distinctive linguistic and community values (McDonnell; Saunders, 1993). Resistance could take macro forms such as the alternative congresses of the Deaf that proposed strong support for signing in schools as well as the employment of Deaf teachers (Lane 1984). Resistance could also take micro forms within ostensibly pure oral schools, where signing became a covert or underground practice (McDonnell; Saunders 1993).

Research in sign languages and Deaf communities has changed our understanding of deafness and has provided new insights in education. It has shown that the important issues for deaf communities are language and culture and that the problems experienced by Deaf students really have little to do with decibels, audiograms, or even cochlear implants. The research has shown that the real barriers are to be found in unsuitable methods of teaching, in inaccessible curricula, in the absence of a working language, in the lack of Deaf teachers and in high levels of inequality (McDonnell 1997).

The emergence of a socio-cultural model of deafness (Ladd, 2003; Lane, 1993) has provided a theoretical and practical framework in the on-going argument in Ireland for the formal recognition of sign languages and for bilingual education for Deaf students. While these have not yet been achieved there were several other significant developments during the 1990s. The national television broadcaster (Radio TelefísÉireann) now includes signed versions of the evening news in its programming and has broadcast magazine programmes on Deaf people and their interests. As a result, public knowledge and awareness of the 
Irish Deaf community and Irish Sign Language has grown considerably.

After being excluded for decades, Deaf people, during this period, again became involved in education, as teachers of Deaf students, as home tutors in ISL, and as special needs assistants in the schools. Perhaps the most significant development has been the establishment of a Centre for Deaf Studies in 2001 in at one of the major universities, Trinity College Dublin. The centre now offers a degree in Deaf Studies, graduate training for ISL teachers and interpreters, and conducts research on Deaf- and ISL - related topics. Core objectives for the Irish Deaf community that remain to be achieved include the recognition of Irish Sign Language as an official language and a greater degree of ISL to be available in the public media, especially television.

\section{Conclusion}

In this paper we have explored the impact of two influential ideologies, normalisation and rights, on disability and deafness. A focus on ideology is worthwhile and relevant because the ideas, meanings and values associated with both disability and deafness are contested fields. These conflicts and uncertainties make an exploration of ideology particularly important for understanding the social, political and cultural implications of disability and deafness. Current debates about what disability and deafness mean, and how they should be interpreted, constitute important sites of struggle for members of these communities.

In Ireland today, normalisation continues to be a very powerful and influential ideology in the interpretation of deafness and in the organisation of responses, especially in the guidance services, in early intervention and in early education. The most authoritative figures in these fields are medical or quasi-medical professionals and responses are premised on a medical discourse of deafness (Mathews, 2011). Moreover, normalisation typically looks to technology and/or administrative change for solutions (Skrtic, 1995). Thus, an increasing incidence of cochlear implantation and an intensive policy of mainstreaming constitute very characteristic normalising practices. Normalisation also exerts considerable influence on disability relations. This is particularly evident in the psycho-medical definitions of disability that inform recent legislation in education and even in equality-related measures (Ireland, 1998a; Ireland, 1998b; Ireland, 2000).

On the other hand, social model theory in the case of disability, and a socio-cultural interpretation of deafness have marked important paradigm shifts in western society. They have revolutionised thinking about disability and deafness and have been responsible for a great deal of anti-discrimination legislation as well as the introduction of structural reforms aimed at creating more inclusive societies. As a result there is an established awareness that the extent to which discrimination is tackled in these fields is a barometer of the overall well-being of society.

Educação \& Realidade, Porto Alegre, v. 41, n. 3, p. 777-788, July/Sept. 2016. 785 
Disability, Deafness and Ideology in the late Twentieth and early Twenty-first Centuries

Received on December 22, 2015

Approved on March 22, 2016

\section{Notes}

1 Change is evident in the unstable terminology that has surrounded debate about disability in recent years (Jenkins, 1998). Zenderland (1998, p. 6), for example notes that what was once called "feeble-mindedness" later became "mental retardation" and, later still, "developmental disability". In this paper, the terms 'disability' and 'disabled people' are used in a socio-political sense to denote a particular form of oppression or discrimination. The term 'impairment' is used to refer to a perceived difference in physical, sensory or intellectual functioning.

2 The term Deaf is used here to indicate membership of a distinctive cultural and linguistic community rather than an audiological impairment (Wrigley, 1996); deafand deafness are used to refer to an audiological condition or where the meaning is ambiguous.

\section{References}

BANNERMAN FOSTER, Susan. The Politics of Caring. Lewes: The Falmer Press, 1987.

BARNES, Colin. Theories of Disability and the Origins of the Oppression of Disabled People in Western Society. In: BARTON, Len (Org.). Disability and Society: emerging issues and insights. Harlow, Essex: Addison Wesley Longman, 1996. P. 43-60.

BARNES, Colin. The Social Model of Disability: a sociological phenomenon ignored by sociologists? In: SHAKESPEARE, Tom (Org.). The Disability Reader: Social Science Perspectives. London: Cassell, 1998. P. 65-78.

BARNES, Colin. A working social model? Disability, work and disability politics in the 21st century. Critical Social Policy, v. 20, n. 4, p. 441-457, 2000.

BARNES, Colin; MERCER, Geoffrey. Disability. Cambridge, UK: Polity Press, 2003.

BARTON, Len. Segregated special education: some critical observations. In:ZARB, Gerry (Org.). Removing Disabling Barriers. London: The Policy Studies Institute, 1995. P. 27-37. CORBETT, Jenny; SLEE, Roger. An international conversation on inclusive education. In: ARMSTRONG, Derrick; ARMSTRONG, Felicity; BARTON, Len (Org.). Inclusive Education: Policy, Contexts and Comparative Perspectives. London: David Fulton, 2000. P. 133-146.

CREAN, Edward. Breaking the Silence: The Education of the Deaf in Ireland. Dublin: Irish Deaf Society Publications, 1997.

DEELEY, S. Professional Ideology and Learning Disability: analysis of internal conflict. Disability and Society, United Kingdom, v. 17, n. 1, p. 19-33, 2002.

FAUGHNAN, Pauline; O'CONNOR, Sile. Major Issues in Planning Services for Mentally and Physically Handicapped Persons. Part II. Dublin: National Economic and Social Council, 1980.

GOFFMAN, Erving. Asylums: essays on the social situation of mental patients and other inmates. New York: Doubleday, 1961.

GRAMSCI, Antonio. Selections from the Prison Notebooks. Translated: Q. Hoare; G. Nowell Smith. London: Lawrence and Wishart, 1971.

HAHN, Harlan. Disability policy and the problem of discrimination. American Behavioural Scientist, Thousand Oaks, v. 28, n. 3, p. 293-318, 1985.

786 Educação \& Realidade, Porto Alegre, v. 41, n. 3, p. 777-788, July/Sept. 2016. 
IRELAND, Department of Education. The Education of Children Who Are Handicapped by Impaired Hearing. The Stationery Office, Dublin, 1972.

IRELAND. Education Act. The Stationery Office, Dublin, 1998a.

IRELAND. Employment Equality Act. The Stationery Office, Dublin, 1998b.

IRELAND. Equal Status Act. The Stationery Office, Dublin, 2000.

JENKINS, Richard. Culture, classification and (in)competence. In: JENKINS, Richard (Org.). Questions of Competence: culture, classification and intellectual disability. Cambridge: Cambridge University Press, 1998. P. 1-24.

KWIOTEK, Rita; MCDONNELL, Patrick. Disability in an equality framework. Studies, v. 92, n. 366, p. 151-160, 2003.

LADD, Paddy. Understanding Deaf Culture: in search of deafhood. Clevedon: Multilingual Matters, 2003.

LANE, Harlan. When the Mind Hears. London: Penguin, 1984.

LANE, Harlan. The Mask of Benevolence: disabling the deaf community. New York: Vintage Press, 1993.

LANE, Harlan. Do Deaf people have a disability? Sign Language Studies, v. 2, n. 4, p. 356-379, 2002.

LANE, Harlan; FISCHER, Renate. Looking Back: a reader on the history of deaf communities and their sign languages. Hamburg: Signum Press, 1993.

LEVINE, Murray. The History and Politics of Community Mental Health. Oxford: Oxford University Press, 1981.

MATHEWS, Elizabeth. 'No sign language if you want to get him talking': power, transgression / resistance, and discourses of $\mathrm{d} /$ Deafness in the Republic of Ireland. Population, Space and Place, v. 17, n, 4, p. 361-376, 2011.

MCADAM, Doug; MCCARTHY, John; ZALD, Mayer. Comparative Perspectives on Social Movements: political opportunities mobilizing structures and cultural framings. Cambridge: Cambridge University Press, 1996.

MCDONNELL, Patrick. Bilingualism and Deaf Education. In: IRISH DEAF SOCIETY SEMINAR BILINGUAL EDUCATION FOR DEAF CHILDREN: BEST OPTION FOR THE FUTURE?, 1997, St. Patrick's College, Drumcondra. Paper. Drumcondra: March 22, 1997. MCDONNELL, Patrick. Inclusive education in Ireland. In: ARMSTRONG, Derrick; ARMSTRONG, Felicity; BARTON, Len (Org.). Inclusive Education: policy, contexts and comparative perspectives. London: David Fulton, 2000. P. 12-26.

MCDONNELL, Patrick. Education policy. In: QUIN, Suzanne; REDMOND, Bairbre (Org.). Disability and Social Policy in Ireland. Dublin: University College Dublin Press, 2003. P. 28-44.

MCDONNELL, Patrick. Disability and Society: Ideological and Historical Dimensions, Dublin: Blackhall Publishing, 2007.

MCDONNELL, Patrick; SAUNDERS, Helena. Sit on your hands: Strategies to prevent signing. In: LANE, Harlan. FISCHER, Renate (Org.). Looking Back: a reader on the history of deaf communities and their sign languages. Hamburg: Signum Press, 1993. P. 255-260.

MERCER, Jane. Labelling the Mentally Retarded. Berkeley: University of California Press, 1974.

MORRIS, Jenny. Independent Lives? Community Care and Disabled People. London: Macmillan, 1993.

OLIVER, Michael. The Politics of Disablement. Basingstoke, UK: Macmillan, 1990. PRIOR, Lindsay. Mind, Body and Behaviour: theorizations of madness and the organisation of therapy. Sociology, v. 25, n. 3, p. 403-422, 1991.

Educação \& Realidade, Porto Alegre, v. 41, n. 3, p. 777-788, July/Sept. 2016. 
Disability, Deafness and Ideology in the late Twentieth and early Twenty-first Centuries

SKRTIC, Thomas. Disability and Democracy: reconstructing (special) education for postmodernity. New York: Teachers College Press, 1995.

SZIVOS, Sue. The limits to integration? In: BROWN, Hellen; SMITH, Hillary (Org.). Normalisation: a reader for the nineties. London: Routledge, 1992. P. 112-133.

TALBOT, J. The Death of the Asylum: a critical study of state hospital management, services and care. New York: Grune and Stratton, 1978.

THOMSON, Mathew. The Problem of Mental Deficiency: eugenics, democracy and social policy in Britain c.1870-1959. Oxford: Clarendon Press, 1998.

TREGASKIS, C. Social model theory: the story so far. Disability and Society, United Kingdom, v. 17, n. 4, p. 457-470, 2002.

TYNE, Alan. Normalisation: from theory to practice. In: BROWN, Hellen; SMITH, Hillary (Org.). Normalisation: a reader for the nineties. London: Routledge, 1992. P. 33-46.

VAIL, David. Dehumanisation and the Institutional Career. Springfield, Ill.: Charles C. Thomas, 1966.

WHITEHEAD, Simon. The social origins of normalisation. In: BROWN, Hellen; SMITH, Hillary (Org.). Normalisation: a reader for the nineties. London: Routledge, 1992. P. 47-59.

WOLFENSBERGER, Wolf. The Principle of Normalisation in the Human Services. Ontario: National Institute on Mental Retardation, 1972.

WRIGLEY, Owen. The Politics of Deafness. Washington, DC: Gallaudet University Press, 1996.

ZENDERLAND, Leila. Measuring Minds: Henry Herbert Goddard and the origins of American intelligence testing. Cambridge: Cambridge University Press, 1998.

Patrick McDonnell is a teacher in a school for deaf pupils in Dublin. He has worked with the Irish Deaf community on a number of projects including the first Irish Sign Lanauge tutor and interpreter training programme to be conducted in Ireland. He also played a key role in efforts to establish the Centre for Deaf Studies which is now located in Trinity College Dublin.

E-mail: patrick.mcdonnell@ucd.ie 